\title{
Identifying Characteristic of Power Quality Problems on Solar Electric Power Generation
}

\author{
*Nurhalim Dani Ali \\ Department of Electrical Engineering, \\ Universitas Riau \\ Pekanbaru, Indonesia \\ nurhalim@lecturer.unri.ac.id
}

*corresponding author: Nurhalim Dani Ali, nurhalim@lecturer.unri.ac.id

\author{
Azriyenni Azhari Zakri \\ Department of Electrical Engineering, \\ Universitas Riau \\ Pekanbaru, Indonesia \\ azriyenni@gmail.com
}

\begin{abstract}
The influence of connected electrical load will cause significant problems on Solar Electric Power Generator (SEPG). The problems are extremely important to be identification in order to provide electrical energy optimally. The objective of this paper is tantamount to investigate the impact of household electrical load on SEPG with variation and continuous electrical load. The identification of power quality was made by marking several test point on each output of SEPG unit. The level quality of voltage and frequency system needed to be measured and observed its performance indicator level. Furthermore, it compared by existing standard. To variation electrical load test, the results showed that the frequency of the system changed from $52 \mathrm{~Hz}$ to $262 \mathrm{~Hz}$. In other hands, the frequency rose about five times against normal frequency. The continuous load test, that frequency of system fluctuated around $52 \mathrm{~Hz}$ to $156 \mathrm{~Hz}$ that also showed abnormal operation of SEPG.
\end{abstract}

Keywords-Energy, Frequency, Power Quality, SEPG.

\section{INTRODUCTION}

The fossil fuel reserves will become depleted in less than the next 10 decades [1]. The fuel is essentially power generation fuel in Indonesia. Power energy crisis cannot be overcome in the brief time because many obstacles in increasing the power plant capacity and network development. Energy conservation program is the best action to face the power energy crisis. Indonesia government issued a few energy policies to reduce the fossil fuel consumption. For instance, rules of President of the Republic of Indonesia number 05 on January, 25, 2006 towards National Energy Policy. The policy arranges energy balance composition with energy mix resources where Indonesia consumed around oil $54 \%$, was $26 \%$, and coal $14 \%$ this year [2].

The ability of PT. PLN (Persero) provides power energy is limited. The average of electricity sales growth in the region of PT. PLN (Persero) in Riau and Riau Island reach around $9.4 \%$ in a year. This growth rate is above the national average growth of $7.57 \%$ in a year and for Sumatra growth of $8.92 \%$. Peak load growth achieves around $5.9 \%$ in a year. This growth has to be controlled because of limited power supply [3]. The number of consumers of the PT. PLN (Persero) for Riau Distribution System always increase every year because the region is anticipated various sectors. This region needs about 3,211.4 MWh in 2008. The electrical energy forecasting stated that this area will need electrical energy consumption around 5632.8 MWh in 2020. The industrial sectors need about $1 \%$ per year. The household sector, the commercial sector, and the social sector demand about 5\% per year [4]. The electrical energy demand rises sharply at 5:00 p.m. to 9:00 pm, it is influenced by the household sector. SEPG is an alternative to overcome this problem. The design of the solar system serves household power energy for peak load period $5 \mathrm{pm}$ to $9 \mathrm{pm}$. It will provide household electrical energy to 67.9 percent. Household electrical energy estimates around 1,300 Wh (watt-hour) in a day. This research was conducted to household customers of PT. PLN (Persero) for 900 VA buyers. This research designed the solar electrical power generator to solve the power system problems in peak load period but the system was not working properly [5].

The solar system performance must be improved in order to work properly; the household consumer equipment will operate normally. The major target of this paper is to identify the frequency and voltage level of SEPG with variation and continuous electrical load. From the results in $[5,6]$, without identifying, there is a relationship between the electrical load and SEPG performance. The performance observed can explain to solve a system problem.

\section{POWER QUALITY PROBLEMS}

Household is the most of electrical energy used in Indonesia and also consume much power energy in the peak load period. SEPG system is an alternative solution for overcoming the scarcity of electrical energy during peak loads, especially for household energy $[5,6]$. SEPG can supply electrical energy household during peak loads. It has a primary energy source that is enormous and unlimited. It contributes as potential energy to provide the household 
power energy. However, solar power system has any problem in terms of power quality. Its power quality problems will damage household appliances, among others, light, fan, and electronic device. Figure 1 and Figure 2 show the wave of power quality problem in power generation.

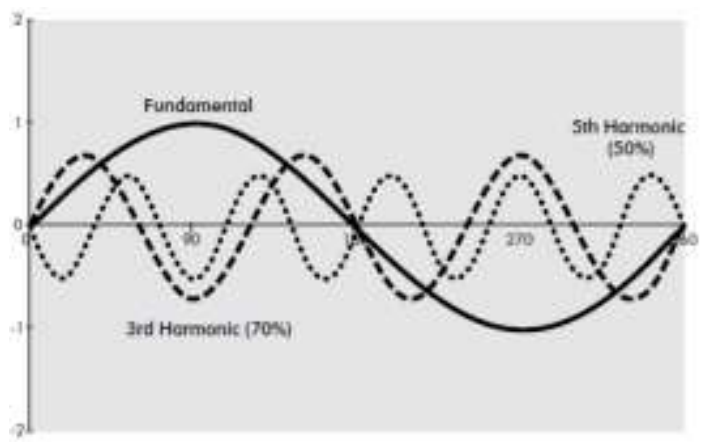

Figure 1: Fundamental voltage wave with third and fifth harmonic.

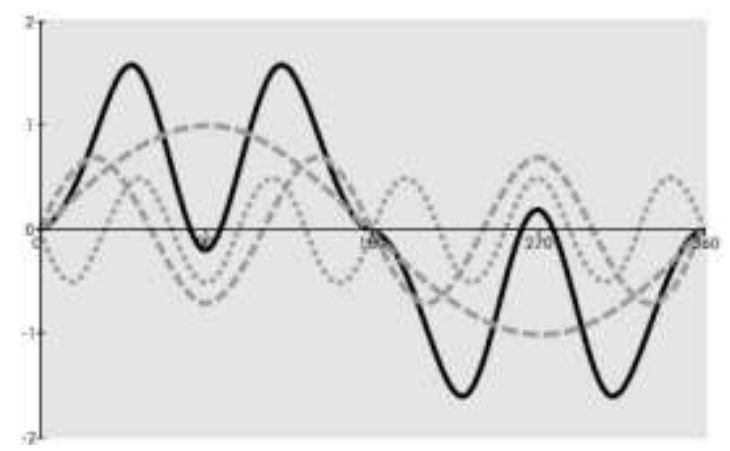

Figure 2: Current harmonic distortion.

\section{RESEARCH METHODOLOGY}

The tests described five points that consist of solar array, regulator, battery bank and inverter. Figure 3 showed the testing point SEPG system. Firstly, the test measured output voltage of solar systems on load condition. The secondly, the frequency of SEPG was observed at the inverter output. The connected load was arranged by variation and continuous type in a certain time. Then, characteristics voltage and frequency of SEPG system will be analyzed.

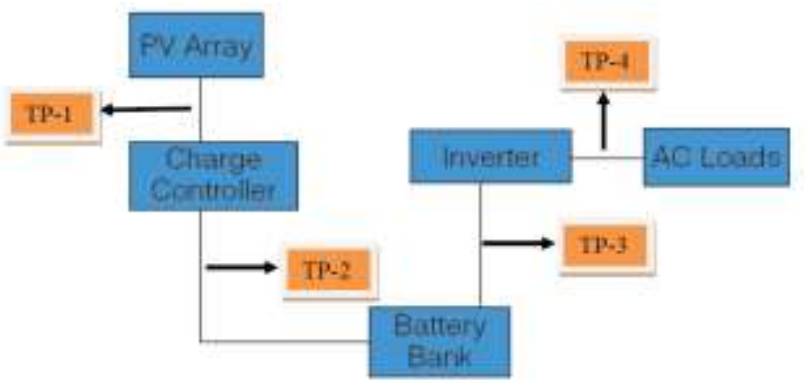

Figure 3: SEPG power quality of testing points.
The test results showed the characteristics of each unit of SEPG. It provided household electrical appliances. This characteristic of deviations from proper circumstances, it is said to power quality disturbances at SEPG.

\section{RESULTS AND DISCUSSION}

\section{A. Power Quality Testing on The Variation of Load}

Load testing is conducted to measure the ability of solar modules to charge the battery bank that serves as energy storage. The diagram of solar modules test is shown in Figure 4.

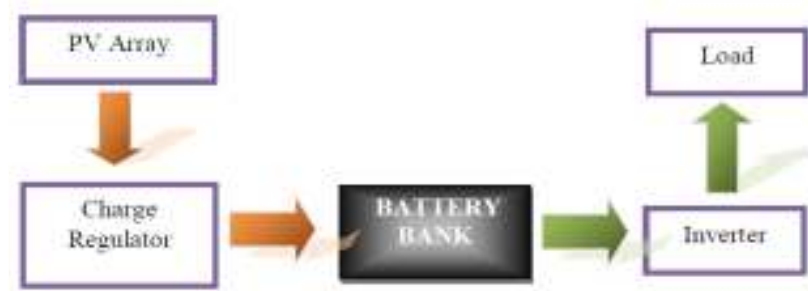

Figure 4: Scheme of the Battery charge and load system.

Table 1: Testing of battery charging

\begin{tabular}{|c|c|c|c|c|}
\hline Stage & Time & $\begin{array}{c}\text { Array } \\
\left(\mathbf{V}_{\text {DC }}\right)\end{array}$ & $\begin{array}{c}\text { Regulator } \\
\left(\mathbf{V}_{\text {DC }}\right)\end{array}$ & $\begin{array}{c}\text { Battery } \\
\left(\mathbf{V}_{\mathbf{D C}}\right)\end{array}$ \\
\hline 1 & 11.00 & 18.29 & 13.8 & 12.52 \\
\hline 2 & 12.00 & 18.57 & 13.8 & 12.64 \\
\hline 3 & 13.00 & 18.6 & 13.8 & 12.66 \\
\hline 4 & 14.00 & 18.76 & 13.8 & 12.68 \\
\hline
\end{tabular}

The test began at 11:00 am where sunlight reaches the optimum point at this time. At the beginning, the battery voltage level 12.52 Volt DC. This level indicates that the battery bank is not empty in a charged state. After being charged for 4 hours, the battery bank reached maximum voltage charge level 12.68 Volt DC. The battery bank had the charging time about 4 hours on the condition of the battery bank voltage 12.52 Volt DC and charging current 18.52 Ampere.

This system supplies alternating current load. Battery bank generates direct voltage and direct current, then, inverter produces an alternating voltage and current when connected to each other. It connected load is switched on and measured changes in electrical quantities at each stage of loading changing. SEPG served energy saving lamps (LHE) on Laptop and PC. Load variation Stage 1 until Stage 7 , then the inverter output voltage and frequency are constant. This is compatible with the voltage and frequency regulation standard available. The inverter output voltage is placed in standard voltage regulation system, which is below 10 percent.

Table 2: The testing of load variation

\begin{tabular}{|c|c|c|c|c|c|}
\hline No & $\begin{array}{c}\text { Battery } \\
\text { Bank } \\
\left(\mathbf{V}_{\text {DC }}\right)\end{array}$ & $\begin{array}{c}\text { Inverter } \\
\left(\mathbf{V}_{\text {AC }}\right)\end{array}$ & $\begin{array}{c}\text { Frequency } \\
(\mathbf{H z})\end{array}$ & $\begin{array}{c}\text { Power } \\
\text { (Watt) }\end{array}$ & Load \\
\hline 1 & 12.45 & 240 & 52 & 7 & LHE Lamp \\
\hline
\end{tabular}




\begin{tabular}{|c|c|c|c|c|c|}
\hline 2 & 12.45 & 240 & 52 & 15 & LHE Lamp \\
\hline 3 & 12.45 & 238 & 52 & 23 & LHE Lamp \\
\hline 4 & 12.45 & 238 & 52 & 34 & LHE Lamp \\
\hline 5 & 12.45 & 237 & 52 & 48 & LHE Lamp \\
\hline 6 & 12.45 & 237 & 52 & 59 & LHE Lamp \\
\hline 7 & 12.45 & 235 & 52 & 124 & $\begin{array}{c}\text { LHE Lamp } \\
\text { and laptop }\end{array}$ \\
\hline 8 & 12.16 & 225 & 262 & 274 & $\begin{array}{c}\text { LHE Lamp } \\
\text { and PC }\end{array}$ \\
\hline
\end{tabular}

Stage 8 displays the fluctuated in power quantity significantly. This value level is out of the standard operation system due to nonlinear load like the personal computer (PC). It non-linear load affects the power quality problem on SEPG. The power quality problem in the system occurs when the frequency is changed from $52 \mathrm{~Hz}$ to $262 \mathrm{~Hz}$. It rises about five times from the fundamental frequency. Figure 5 describes system power quality problems on load.

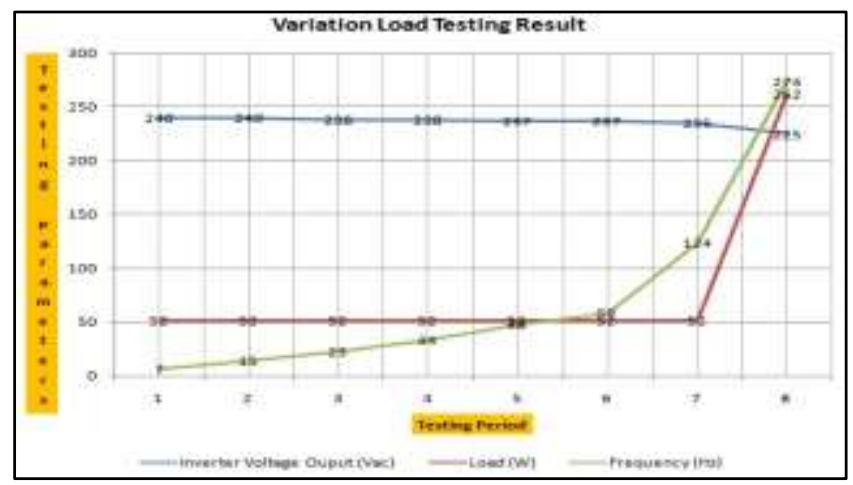

Figure 5: Frequency and voltage changing on variation loads.

\section{B. Power Quality Testing on Continuous Load}

The SEPG supplies a continuous load for five hours. The output voltage level of the battery bank and inverter is located in safety regulation range. On this test indicates the frequency change from $52 \mathrm{~Hz}$ to $156 \mathrm{~Hz}$ which the frequency increases into three time. The power quality and characteristics of the power system is shown in Figure 6.

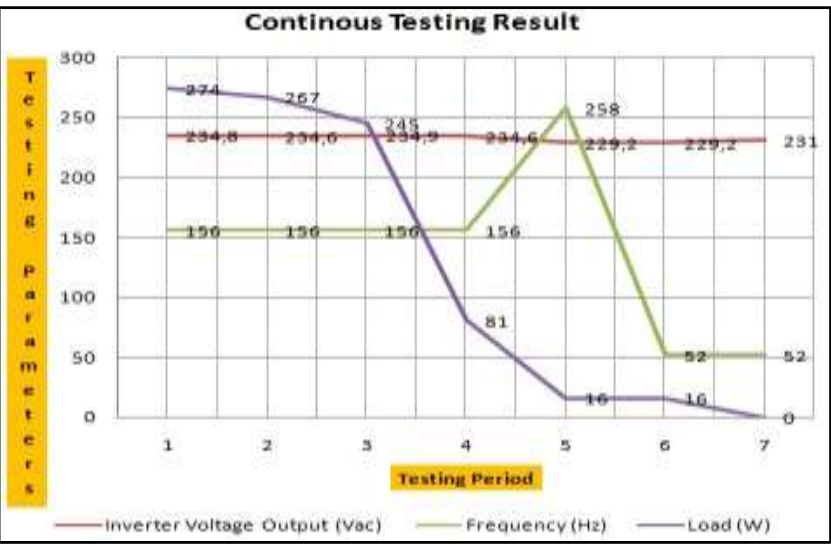

Figure 6: Frequency and voltage changing on continuous loads

\section{CONCLUSION}

Household electrical load generates a power quality problem of SEPG system. The problem has been shown by frequent fluctuation from $52 \mathrm{~Hz}$ ascending into $262 \mathrm{~Hz}$. Furthermore, on continuous load testing, the frequency increased from $52 \mathrm{~Hz}$ to $156 \mathrm{~Hz}$ that it indicates a power quality problem where the frequency rose about three times the fundamental value. On the inverter output voltage, the voltage regulation rate is a safe voltage operation that it still below 10 percent. So in this article can be explained that the power quality disturbances at SEPG are only frequency interference. Furthermore, SEPG needs a harmonic filter in order to work properly.

\section{REFERENCES}

[1] V. K. Eswarlall, et.al, "Enhanced Renewable Energy Adoption for Sutainable Development in India: Interpretive Structural Modeling Approach", World Renewable Energy Congrees, Lingkoping, Sweden, 2011.

[2] Nurhalim, "Theoretical analysis of Biofuel Development Prospects For Future Energy in Indonesia", Jurnal Teknos-2K, Faculty of Industrial and Technology, University of Bung Hatta, 2009.

[3] PT. PLN (Persero), "Power System Provision Planning in Wilayah Riau and Kepulauan Riau on 2010-2019", Riau, Indonesia, 2009.

[4] Nurhalim, Firdaus, "Analysis of Electricity Load Forecast Riau Sub System of PT. PLN (Persero)", National Conference, Faculty of Engineering, University of Riau, Pekanbaru, 2010.

[5] Nurhalim., et.al, "Solar Electric Power Generator (SEPG) as a Solution for Peak Load in Household Sector as Energy Conservation System: A Case Study in Pekanbaru City of Indonesia", International Conference and Utility Exhibition on Power and Energy Systems: Issues and Prospects for Asia (ICUE), Amari Orchid, Pattaya City, Thailand, 2011.

[6] Nurhalim., et.al, "Solar Electric Power Generator (SEPG) as a Solution fo Peak Load in Household Sector as Energy Conservation System: a Case Study in Pekanbaru City of Indonesia", Publisher: IEEE Explore, ISBN: 978-1-4673-6006-7, 2011.

[7] David Chapman, "Harmonics Causes and Effects. Copper Development Association", United Kingdom, 2001. 